\title{
METODE TAFSĪR TAḤLĪLī
}

\author{
Sabil Mokodenseho \\ Sekolah Pascasarjana UIN Syarif Hidayatullah Jakarta \\ sabil.mokodenseho@gmail.com
}

\section{PENDAHULUAN}

Kajian atas tafsir atau penafsiran ayat-ayat al-Qur'an penting untuk dilakukan sebab al-Qur'an adalah pedoman bagi umat (Islam), memuat informasi dan pesan-pesan penting dari Allah Swt. tentang bagaimana seharusnya manusia bertindak di muka bumi, yang sesuai dengan syariat Islam. Pada saat yang sama, harus diakui bahwa dalam mengarungi hidup, setiap manusia memiliki kebutuhan yang amat beragam, pun dengan masalah yang diperhadapkan padanya. Sebagaimana fungsinya, yakni pedoman dan petunjuk, ${ }^{1}$ al-Qur'an harus mampu menjawab tantangan zaman, baik yang terjadi di masa lalu, sekarang, dan akan datang, sehingga derajatnya selalu terjaga, utamanya dari mereka yang tidak mempercayainya.

Pada dasarnya al-Qur'an memuat penjelasan-penjelasan yang masih umum. Meminjam bahasa Muhammad Arkoun (1928-2010 M), ayat-ayat al-Qur'an memberikan kemungkinan-kemungkinan arti yang tidak terbatas. Senada dengan Arkoun, Shihab mengatakan ayat al-Qur'an tertutup dalam interpretasi tunggal, artinya ia selalu terbuka untuk diinterpretasikan ${ }^{2}$ dalam rangka menemukan jawaban dan penjelasan atas segudang pertanyaan maupun penemuan jawaban dari permasalahan yang muncul kemudian. Namun, meski demikian pentingnya penafsiran harus dilakukan, tetapi yang perlu dicatat dan diketahui adalah bahwa tidak semua orang dapat menafsirkan al-Qur'an. Banyak persyaratan yang harus dipenuhi atau dimiliki mufasir dalam menafsirkan al-Qur'an, utamanya dari segi

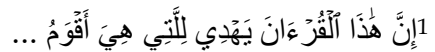

Terjemahnya: “Sungguh, al-Qur'ān ini memberi petunjuk ke (jalan) yang paling lurus...". (QS. Al-Isra' [17]: 9)

${ }^{2}$ Muhammad Quraish Shihab, Membumikan al-Qur'ān (Bandung: Mizan, 1992), 72 . 
penguasaan ilmu dan mental. ${ }^{3} \mathrm{Hal}$ ini menjadi penting sebab dapat memengaruhi kualitas penafsiran yang dilakukan, termasuk penggunaan metode yang digunakan mufasir ikut membuat corak tafsir itu beragam antara satu dengan yang lainnya.

Secara historis, penggunaan metode tafsir dalam dinamika dan perkembangan tafsir al-Qur'an, mufasir pada umumnya menggunakan beberapa metode tafsir yang diklasifikasikan menjadi empat metode, yaitu ijmāli (global), tạ̣līlì (analisis), maudhü'i (tematik), dan muqārin (perbandingan). ${ }^{4}$ Setiap metode tersebut, selain memiliki keistimewaan, juga terdapat kelemahankelemahannya. Kendati demikian, penggunaan beberapa metode tersebut telah digunakan dan disesuaikan dengan maksud yang ingin dicapai. ${ }^{5}$ Namun, tidak berarti penafsiran telah selesai, justru ini masih menyisakan atau menunjukkan bahwa ilmu tafsir al-Qur'an sebagai salah satu cabang dari ilmu keislaman, belum matang.

Penjelasan di atas menjadi salah satu pertanda bahwa penafsiran al-Qur'an masih terus berkembang dan terbuka untuk dikembangkan sebagaimana pendapat Thomas Kuhn yang dikutip Ilyas bahwa perkembangan tafsir al-Qur'an berlangsung secara dialektik dan revolusioner dalam periode tafsir pra modern (abad 1$12 \mathrm{H}$ ) dan periode modern (abad $12 \mathrm{H}$. sampai sekarang). ${ }^{6}$ Dinamika perkembangan ilmu tafsir berbanding lurus dengan permasalahan dan tantangan zaman yang umat Islam hadapi hingga hari ini. Cikal

'Lihat Muhammad Ibrahim, Rawai' al-Bayan fì 'Ulūm al-Qur'ān (Mesir: Dār alTaba'ah Muhammadiyah, 1984), 135, 138-143.; Muhammad Husain al-Dzahabī, AlTafsìr wa al-Mufassirun, juz 1 (Kairo: Dār al-Kutub al-Haditsah, 1986), 175-177, 181.; Syihabuddin Mahmud al-Alūsī, Manhaj al-Alūsī, (Mesir: Majlis al-A'la, 1989), h. 1112.; Al-Qattan, Mabahits fì 'Ulūm..., 462-466.; Jalāluddīn al-Suyūțī, Al-Itqan fì 'Ulūm al-Qur'àn, (Beirūt: Maktabah Ashriyyah, 2008), 869-870.

"Badri Khaeruman, Sejarah Perkembangan Tafsìr al-Qur'ān (Bandung: CV. Pustaka Setia, 2004), 94.

${ }^{5}$ Muhammad Quraish Shihab, Kaidah Tafsìr: Syarat, Ketentuan, dan Aturan yang Patut Anda Ketahui dalam Memahami Ayat-ayat al-Qur'ān, (Jakarta: Lentera Hati, 2013), h. 377.

${ }^{6}$ Hamim Ilyas, "Hermeneutika al-Qur'ān: Studi Tafsir Modern." Tarjih: Jurnal Tarjih dan Pengembangan Pemikiran Islam, 6, no. 1 (2003): 52-61.; Hamim Ilyas, "Kata Pengantar," dalam Studi Kitab Tafsìr (Yogyakarta: Teras, 2014), IX. 
bakal adanya tafsir al-Qur'an erat kaitannya dengan upaya ijtihād yang dilakukan sahabat-sahabat nabi, terutama pasca wafatnya Nabi Muhammad Saw., untuk mengatasi problem aktual yang muncul berdasarkan penjelasan ayat al-Qur'an dan hadis. Problem ini terjadi sebab kandungan al-Qur'an tidak secara menyeluruh dan rinci dijelaskan pada masa Nabi Muhammad Saw. ${ }^{7}$

Sebuah tafsir al-Qur'an yang dihasilkan mufasir, yang kemudian disajikan, khususnya kepada yang membutuhkan dan para pembaca pada umumnya, tentu tidak dapat dilepaskan dari halhal yang membantunya untuk sampai pada kejelasan dan kepahaman atas teks al-Qur'an. Alat yang digunakan untuk menjelaskan dan menafsirkan ayat-ayat al-Qur'an adalah dengan menggunakan metode, salah satunya adalah metode tahlìlī (analisis) sebagaimana fokus tulisan ini. Metode ini muncul, salah satunya disebabkan atas ketidakpuasan sebagian mufasir terhadap metode ijmāli yang digunakan oleh mufasir yang lain dalam menafsirkan ayat al-Qur'an karena dianggap tidak mengakomodir penafsiran al-Qur'an yang sebenarnya membutuhkan analisis yang memadai dan mendalam. Pada saat yang sama, perkembangan dan jumlah umat Islam saat ini tidak hanya yang berasal dari bangsa Arab tetapi juga dari kalangan non-Arab, termasuk permasalahan yang dihadapi cukup beragam. Dengan begitu, perubahan dalam wacana pemikiran Islam pun tidak dapat dihindari dimana peradaban yang beragam dan tradisi non-Islam turut berbaur dalam khazanah intelektual Islam serta memengaruhi kehidupan umat. Oleh karenanya, para mufasir yang memiliki kualifikasi di bidang ini berupaya menyajikan penafsiran ayat al-Qur'an yang sejalan dengan perkembangan, dinamika dan kebutuhan umat yang beragam sebagaimana yang telah diuraikan.

Untuk itu, tulisan ini dimaksudkan untuk membahas metode tafsir tahlīlī (analisis) dalam penafsiran al-Qur'an. Secara khusus

${ }^{7}$ Muhammad Quraish Shihab, Membumikan al-Qur'ān: Fungsi dan Peran Wahyu dalam Kehidupan Masyarakat (Bandung: Mizan, 2012), 71. 
tulisan ini membahas dan menganalisis beberapa hal, yaitu: (1) metode tafsir: tahlīil tinjauan etimologi dan terminologi; (2) dinamika dan perkembangan metode tafsir tahlìì; (3) karya tafsir, (4) contoh penafsiran; (5) keunggulan dan kelemahan.

\section{PEMBAHASAN}

\section{Metode Tafsir Taḥlīlī: Tinjauan Etimologi dan Terminologi}

Sebelum masuk pada penjelasan secara rinci kaitannya dengan penggunaan metode taḥlìli dalam penafsiran al-Qur'an, ada baiknya dikemukakan terlebih dahulu analisis terhadap sejumlah definisi tentang metode, tafsir dan tahlìli, baik secara etimologi maupun terminologi. Kata "metode" dalam bahasa Arab diterjemahkan dan disinonimkan dengan kata "manhaj" (cara; metode) ${ }^{8}$ dan "țarīqah" (jalan; cara). ${ }^{9}$ Sementara, metode dalam etimologi Inggris disebut "method"10 yang diartikan sebagai cara melakukan sesuatu secara sistematis: logis dan teratur (biasanya dalam langkah-langkah). Merujuk pada etimologi Indonesia, metode dapat dimaknai sebagai suatu cara teratur mencapai maksud dan tujuan. Sehingga bisa disimpulkan bahwa metode dalam kaitannya dengan ilmu pengetahuan adalah sebagai cara kerja yang teratur dan saling berkaitan, membentuk suatu totalitas untuk memudahkan pekerjaan guna mencapai tujuan yang ditentukan.11 Demikian halnya dalam konteks ilmu tafsir atau penafsiran al-Qur'an, metode dapat dipahami sebagai seperangkat kaidah yang mengatur seorang mufasir agar

${ }^{8}$ Ahmad Warson Munawwir, Kamus Al-Munawwir Arab-Indonesia (Surabaya: Pustaka Progressif, 1997), 1567.

9Munawwir, Kamus Al-Munawwir..., 910-1645. Kata "manhaj" dan "țarīqah" kemudian dijelaskan oleh Hans Wehr. Menurutnya, kata "țarīqah" yang bentuk jamak atau pluralnya țarāiq dapat berarti (metode, cara, jalan, alat, mode, dan program), sedangkan kata "manhaj" yang bentuk jamak atau pluralnya manāhij mengandung arti (terbuka, dataran, metode, jalan, cara, dan program). Lihat Hans Wehr, A Dictionary of Modern Written Arabic. Edited by J. M. Cowan (London: Macdonald and Evans Ltd., 1995), 559.

${ }^{10}$ Noah Webster, Webster's New Twentieth Century Dictionary (New York: William Collins, 1980).

11Tim Penyusun Departemen Pendidikan Republik Indonesia, Kamus Besar Bahasa Indonesia (KBBI) (Jakarta: Balai Pustaka, 2008), 580-581. 
terhindar dari kesalahan maupun penyimpangan pada saat menafsirkan ayat al-Qur'an. ${ }^{12}$

Kata "tafsīr" mengikuti pola dasar (وَزْنُ) tafil, berasal dari etimologis Arab فسّر 13 تفسير yang merupakan bentuk mașdar14 dari kata $(\text { fasr })^{15}$ artinya al-ị̂ăh, al-sharh dan al-bayān ${ }^{16}$ (keterangan; penjelasan). ${ }^{17}$ Senada dengan pengertian itu, Kamus Besar Bahasa Indonesia (KBBI) mendefinisikan kata "tafsir" sebagai keterangan atau penjelasan ${ }^{18}$ tentang ayat al-Qur'an. Kata "tafsīr" juga dapat bermakna menerangkan (al-ibānah), menyingkap (al-kashf) dan menampakkan makna rasional (iẓhār al-ma'nā al-ma'qūll). ${ }^{19}$ Merujuk pada beberapa

12Supiana dan M. Karman, 'Ulumul Qur'ān dan Pengenalan Metodologi Tafsir (Bandung: Pustaka Islamika, 2012), 302.

${ }^{13}$ Kata tafsìr menurut pendapat lain, berasal dari safru (dengan menukar posisi sin dengan $f a^{\prime}$ ) sebagaimana kata orang Arab "asfara al-suḅ̣ idhā aḍā'a" (apabila shubuh itu telah bersinar). Juga berasal dari kata tafsirah, yaitu nama dari alat yang dipakai seorang dokter untuk mengetahui atau menganalisis keluhan seorang pasien. Lihat Jalāluddīn al-Suyūțī, Al-Itqān fì 'Ulūm al-Qur'ān, juz II (Beirūt: Dār al-Fīkr, 1979), 173.

${ }^{14}$ Mașdar merupakan bentuk kata benda (nomina; noun) yang dibentuk dari kata kerja (verba; verb) dan menunjukkan peristiwa, serta harus mengandung keseluruhan huruf yang ada pada kata kerjanya, kecuali untuk alasan yang berkaitan dengan ilmu bentuk kata (morfologi; morphology). Lihat Aiman A. Abdul Ghani, Al-Nahwu al-Kafi, ed. 1 (Kairo: Dār al-Taufiqiyyah wa al-Turats, 1998), 215.

${ }^{15 K a t a ~(ف س ّ ر) ~ j u g a ~ d i j e l a s k a n ~ I b n ~ M a n z u ̄ r ~ s e b a g a i ~ " m e n y i n g k a p ~ s u a t u ~ h a l ~ y a n g ~}$ tertutup, sedangkan tafsīr menyingkap makna yang dikehendaki dari lafadz musykil." Lihat Ibn Manẓūr, Lisān al-'Arab 5 (Beirūt: Dār Ṣādir, t.th.), 55.

${ }^{16}$ Louis Ma'lūf al-Yasū'i, Al-Munjid fì al-Lughah wa al-A'lām (Beirūt: Dār alMashriq, 1986), 583.

${ }^{17} \mathrm{Al}-\mathrm{Khālid} \bar{i}$ dengan merujuk dalam kitab Maqāyīs al-Lughah karangan ibn Faris, mendefinisikan kata "tafsīr" dengan makna "penjelasan sesuatu" atau "mengungkap maksud dari makna yang musykil" sebagaimana yang ia rujuk dalam kitab Lisān al-'Arab. Lihat Șalāh Abdu al-Fattāh al-Khālidī, Al-Tafsìr alMaudhū'i baina al-Nazhariyyah wa al-Tathbīq, ed. 1 (Yordania: Dār al-Nafais, 1997), 11.; Kata "tafsīr" dengan makna "keterangan dan penjelasan" terdapat dalam alQur'ān, misalnya, dalam ayat yang artinya: "Tidaklah orang-orang kafir itu datang kepadamu membawa sesuatu yang ganjil melainkan kami datangkan kepadamu sesuatu yang benar dan yang paling baik penjelasannya." (QS. Al-Furqān [25]: 33).

${ }^{18}$ Tim Penyusun, Kamus Besar Bahasa..., h. 1356.

${ }^{19}$ Penjelasan secara rinci dapat dibaca dalam karya Mannā' Khalil al-Qațāan, Mabāhith fì 'Ulūm al-Qur'ān (Riyāḍ: Manshūrat al-'Așr al-Hadīth, t.th.), 323.; Muhammad Ali al-Ṣābūnī, Al-Tibyān fì 'Ulūm al-Qur'ān (Jakarta: Dār al-Kutub alIslāmiyyah, 2003), 65. 
definisi etimologis yang dikemukakan, tafsir dapat digunakan untuk menyingkap hal-hal yang bersifat indrawi dan maknawi (makna rasional dari suatu teks), ${ }^{20}$ tetapi pemakaian tafsir dengan makna yang kedua lebih banyak digunakan daripada yang pertama. Dari beberapa etimologis tafsir, ahli 'Ulūm al-Qur'ān merumuskan definisi tafsir adalah sebagai "penjelasan; keterangan; penyingkapan". ${ }^{21}$

Para ulama kemudian mendefinisikan kata "tafsir" secara terminologi. Sebagian ahli tafsir menyatakan tafsir tidak masuk dalam jajaran ilmu pengetahuan (sains) yang memiliki batasan tertentu. Hal tersebut didasarkan pada sebuah pemikiran bahwa tafsir tidak mempunyai kaidah dan batasan-batasan khusus, sebagaimana yang berlaku pada ilmu sains yang dihasilkan akal manusia. ${ }^{22}$ Namun, sebagian ahli tafsir memasukan tafsir ke dalam cabang ilmu pengetahuan, Karena dalam tafsir termuat ragam topik tertentu yang pada sebenarnya membutuhkan campur tangan dari beberapa kaidah keilmuan yang digunakan sebagai dasar pijakan dalam ilmu tafsir. Dengan pertimbangan tersebut, maka tafsir dimasukkan dan dikategorikan ke dalam salah satu ilmu pengetahuan ilmiah. ${ }^{23}$

Menurut al-Zarkashī (w. 1392)24 dan al-Ṣabbāgh²5 tafsir adalah ilmu memahami kitab Allah (al-Qur'an), yang diturunkan kepada Nabi Muhammad Saw., menerangkan maknanya, mengeluarkan hukumnya, dan mengungkap hikmah yang dikandungnya. Lebih spesifik, Abū Ḥayyān mendefinisikan tafsir sebagai ilmu tentang tata

${ }^{20}$ Khālid 'Abd al-Rahman al-'Ak, Ușūl al-Tafsīr wa Qawā'iduhu (Beirūt: Dār alNafā'is, 1986), 30.

${ }^{21}$ Al-Qațțān, Mabāhith fí 'Ulūm..., 27.; Al-Ṣābūnī, Al-Tibyān fì 'Ulūm..., 65.; Al'Ak, Ușūl al-Tafsìr wa ..., 30.

${ }^{22}$ Nashruddin Baidan, Wawasan Baru Ilmu Tafsīr (Yogyakarta: Pustaka Pelajar, 2005), h. 67.

23Baidan, Wawasan Baru Ilmu..., 30.

${ }^{24}$ Badruddīn Muhammad bin Abdullah al-Zarkashī, Al-Burhān fì 'Ulūm alQur'ān 1 (Kairo: Maktabah Dār al-Turāth, t.th), 13.; Badruddīn Muhammad bin Abdullah al-Zarkashī, Al-Burhān fì 'Ulūm al-Qur'ān, jilid 1 (Beirūt: Dār al-Kutub al'Ilmiyah, 2008), 13.

${ }^{25}$ Muhammad bin Luṭ̂̄ al-Ṣabbāgh, Lamhāt fì 'Ulūm al-Qur'ān wa Ittijāh alTafsìr (Beirūt: al-Maktab al-Islami, 1990), 187. 
cara mengucapkan (membunyikan) lafadz al-Qur'an, sesuatu yang terindikasikan darinya, hukum-hukumnya baik mengenai kata-kata tunggal maupun tarkib, makna-makna yang menjadi implikasi keadaan susunannya dan segala sesuatu yang dapat menyempurnakannya (di dalamnya: mengetahui nasakh, asbäbun $n u z \bar{u} l$, kisah yang menjelaskan sesuatu yang masih samar atau mubham, dan semua yang berkaitan dengannya). ${ }^{26}$ Tidak jauh beda dengan Abū Ḥayān, al-Suyūṭi mendefinisikan tafsir sebagai ilmu yang membahas turunnya ayat al-Qur'an, kondisi-kondisinya, kisahkisahnya, asbābun nuzūl, urut-urutan makki-madanì-nya, muhkam mutashābih-nya, nāsikh mansūkh-nya, 'ām-khās-nya, muțlaq muqayyadnya, mujmal mufassar-nya, halal dan haramnya, janji dan ancaman, perintah dan larangan, teladan-teladannya dan perumpamaanperumpamaannya. ${ }^{27}$

Mudahnya, tafsir al-Qur'an dilakukan untuk menjelaskan arti dan maksud dari firman Allah Swt., (ayat-ayat al-Qur'an) baik secara teks maupun konteks, ${ }^{28}$ serta sesuai dengan kemampuan manusia ${ }^{29}$ yang dalam hal ini adalah mufasir. Artinya, perbedaan latarbelakang, keilmuan dan kemampuan mufasir memengaruhi atau membuat keanekaragaman penafsiran tidak dapat dihindarkan. Keanekaragaman dalam penafsiran tersebut juga terlihat dari segi penggunaan metode tafsir, yang salah satunya adalah metode tahlili sebagaimana dalam konteks tulisan ini.

Kata "tahlīilì" (تحليلي) merupakan kata sifat yang dibentuk dari maṣdar (kata dasar) تحليل dan diakhiri dengan huruf ي, makna

${ }^{26}$ Abū Ḥayān, Tafsīr al-Bahr al-Muhīt 1 (Beirūt: Dār al-Kutub al-'Ilmiyah, 1993), 13.

${ }^{27}$ Al-Suyūțī, Al-Itqān fì 'Ulūm..., 2, 174.

${ }^{28}$ Abdul Djalal HA, Urgensi Tafsìr Mauḍ̄'ì Pada Masa Kini (Jakarta: Kalam Mulia, 1990), 6.

${ }^{29}$ Lihat Muṣtafā Muslim, Mabāhith fi Tafsīr al-Mauḍ̄'ì (Damashkus: Dār alQalam, 1989), 15.; Abd al-'Azhim al-Zarqani, Manāhil al-Irfān fí 'Ulum al-Qur'ān, jilid II (Mesir: Mustafa al-Babi al-Habi, t.th), 6.; Muhammad Ḥusain al-Dhahabī, Al-Tafsìr wa al-Mufassirūn 1, cet. 2 (Mesir: Dār al-Kutub al-Haditsah, 1976), 2.; Muhammad Husain al-Dhahabī, Al-Tafsìr wa al-Mufassirūn 1 (Kairo: Maktabah Wahbah, 2000), 14. 
leksikalnya adalah analisis. ${ }^{30}$ "Taḥlīlī" juga bisa berarti "membuka sesuatu; tidak menyimpang darinya;31 membebaskan".32 Merujuk dalam $M u^{\prime}$ jam al-Ma'ani, "tahlilili" adalah proses membagi hal-hal yang sifatnya masih umum ke dalam bagian yang lebih rinci, dan mengembalikan sesuatu kepada unsur-unsurnya. ${ }^{33}$ Merujuk dalam Cambridge Academic Content Dictionary, analisis adalah proses mempelajari atau memeriksa sesuatu dengan cara yang terorganisir untuk mempelajari lebih lanjut tentang hal itu, atau studi tertentu tentang sesuatu. ${ }^{34}$ Sementara dalam Kamus Besar Bahasa Indonesia, analisis adalah penyelidikan terhadap suatu peristiwa (perbuatan) untuk mengetahui kondisi yang sebenarnya (sebab musabab) dimana penguraian suatu pokok atau berbagai bagian untuk mendapatkan definisi yang tepat, dan pemahaman arti secara komprehensif. 35

Ulama memberikan definisi tentang terminologi tahlilì, baik dalam kaitannya dengan metode maupun penafsiran. Menurut alFarmawī (1942-2017) metode taḥlìli adalah menjelaskan ayat-ayat alQur'an dengan cara meneliti dan menyingkap semua aspek dan maksudnya, yang dimulai dari menjelaskan kosakata, makna kalimat, maksud setiap ungkapan, kaitan-kaitan (munāsabah) dan berbagai aspeknya, asbābun nuzūl, riwayat-riwayat Nabi Saw., sahabat dan tabi'in. Adapun prosedurnya, dilakukan mengikuti susunan mushaf, ayat per ayat, atau per surat. Biasanya juga menyertakan sejumlah uraian kebahasaan dan materi khusus lainnya, yang keseluruhannya

30"Tahlīl" diterjemahkan dengan analysis, analyzation, sedangkan "taḥlīlī" diterjemahkan analytic (al). Lihat Rohi Baalbaki, Al-Mawrid: A Modern Arabic-English Dictionary (Beirūt: Dār el-'Ilm lil Malayin, 1995), 290.

${ }^{31}$ Ahmad bin Faris bin Zakariya Abul Husein, Mu'jam Maqāyis al-Lugah, juz II, (Beirūt: Dār al-Fīkr, 1979), 20.

32Ibn Manẓūr, Lisān al-' Arabi, juz 11 (Beirūt: Dār Ṣādir, 2010), 163.

33"Mu'jam al-Ma'āni," diambil dari: https://www.almaany.com/ar/dict/arar/. Diakses pada 04 Mei 2021.

34"Cambridge Academic Content Dictionary," diambil dari: https://dictionary.cambridge.org/dictionary/english/analysis. Diakses pada 04 Mei 2021.

${ }^{35}$ Kamus Besar Bahasa Indonesia (Jakarta: Balai Pustaka, 1990), 32. 
dimaksudkan untuk memahami ayat al-Qur'an. ${ }^{36}$ Senada dengan itu, merujuk dalam karya Ibrahim Khalifah dijelaskan bahwa tafsir tahlili adalah penjelasan ayat al-Qur'an dalam segala aspek secara komprehensif. Dalam konteks ini, mufasir menjelaskan ayat dalam surat secara ayat demi ayat, menjelaskan kosa kata, mengarahkan kedudukan setiap kata dalam struktur kalimat (i'rab), menjelaskan makna kalimat, menjelaskan rahasia dan hukum yang menjadi tujuan dari struktur-strukturnya, serta menjelaskan munāsabah ayat dan surat menggunakan bantuan ayat al-Qur'an, asbābun nuzūl, hadits Nabi Saw., perkataan sahabat dan tabi'in, dan ilmu bantu lainnya, yang mendukung mufasir dalam memahami teks al-Qur'an. ${ }^{37}$

Selain beberapa terminologi di atas, Quraish Shihab mendefinisikan metode tahlìli sebagai metode menjelaskan ayat-ayat al-Qur'an dari berbagai segi sesuai pandangan, kecenderungan, dan keinginan mufasir. Langkah-langkah yang harus dilakukan mufasir adalah dengan menyajikan secara runtut sesuai urutan ayat dalam mushaf, yang mencakup pengertian umum kosa kata ayat, munāsabah ayat dengan ayat sebelumnya, asbābun nuzūl (jika ada), makna global ayat, hukum yang dapat ditarik, dan adakalanya juga disertakan pendapat ulama mazhab. Bahkan, ada yang menambahkan ragam qirāat, dan i'rab ayat yang ditafsirkan, serta keistimewaan susunan kata. Adapun fokus penafsirannya, ada yang bercorak kebahasaan, hukum, sosial-budaya, falsafī (sains; ilmu pengetahuan), tasawuf/ishārī, dan sebagainya. ${ }^{38}$

Dengan demikian, dapat disimpulkan bahwa metode tafsir tahlili ${ }^{39}$ adalah metode tafsir yang sistematis karena kandungan ayat-

${ }^{36}$ Abd al-Hayy Hussein al-Farmāwī, Al-Bidāyah fì al-Tafsìr al-Mauḍh' $\bar{\imath}$ : Dirāsah Manhajiyyah Maudhū'iyyah, cet. II (Kairo: Matṭba'ah al-Ḥaḍārah al'Arabiyyah, 1977).

${ }^{37} \mathrm{Ibrahim}$ 'Abdu al-Rahman Khalifah, Al-Mausū'ah al-Qur'āniyyah alMutakhașșișah (Kairo: Al-Majlis al-A'la li al-Syuun al-Islamiyyah, 2006), 278.

38Muhammad Quraish Shihab, Kaidah Tafsìr (Tangerang: Lentera Hati, 2013), 378.; Shihab, Membumikan al-Qur'àn, 72-73.

${ }^{39}$ Metode tafsīr tahlīlì disebut juga oleh Baqir al-Shadr $(1353-1400 \mathrm{H})$ sebagai metode tajzi'iyah (metode tafsir yang menjelaskan berdasarkan bagian- 
ayat al-Qur'an dijelaskan berdasarkan urutan ayat dalam mushaf dan ditinjau dari berbagai segi, yakni mufaradāt dan munāsabah ayat untuk melihat hubungan antara ayat sebelum dan sesudahnya, asbābun nuzūl, makna ayat secara global, tinjauan hukum yang terkandung dan tambahan penjelasan kaitannya dengan qirāat, i'rab dan keistimewaan susunan kata pada ayat yang ditafsirkan serta diperkaya dengan pandangan imam mazhab dan sebagainya.

\section{Perkembangan Metode Tafsir Taḥlīlī}

Penafsiran al-Qur'an umumnya dilakukan menggunakan empat metode penafsiran, ${ }^{40}$ yaitu ijmāli (global), taḥlìli (analisis), muqarin (perbandingan), dan maudhu'i (tematik). Namun, sebagaimana pada judul dan tanpa mengesampingkan metode tafsir yang lain, tulisan ini dikhususkan untuk membahas dan mengelaborasi metode tahlili dalam penafsiran ayat al-Qur'an.

Tafsir tahlìli dalam sejarah dan perkembangannya telah mengalami beberapa fase. Pada fase awal, tafsir ini hanya terdiri dari penafsiran atas kata-kata yang ambigu dan sulit dipahami. Sementara penafsiran terhadap kata-kata secara kebahasaan jarang sekali dilakukan pada masa hidupnya Nabi Muhammad Saw., karena tidak adanya kebutuhan dari masyarakat. Hal ini dapat dimaklumi sebab kualitas dan kemampuan bahasa dari masyarakat setempat masih sangat kuat, serta kehidupan mereka belum bercampur dengan orang-orang non-Arab ('Ajam) yang bahasa ibunya bukan bahasa Arab. ${ }^{41}$ Oleh karenanya, pada masa Nabi Muhammad Saw., tafsir secara kebahasaan belum menjadi sebuah kebutuhan atau belum ada sebagaimana yang berlaku pada masa setelahnya.

Berlanjut pada fase kedua di mana terjadi perluasan penafsiran secara besar-besaran. Hal itu menjadi kebutuhan primer bagi

bagian/penafsiran parsial). Lihat Muhammad Baqir al-Shadr, Al-Tafsìr al-Maudhū' $\bar{\imath}$ wa al-Tafsìr al-Tajzii fil Qur'ānil Karìm (Beirūt: Dār al-Ta'aruf), 9.

${ }^{40}$ Nashruddin Baidan, Metodologi Penafsiran al-Qur'ān (Yogyakarta: Pustaka Pelajar, 1998), 9.

${ }^{41}$ Muhsin Abd al-Hamid, Tathawwur Tafsìr al-Qur'ān (Dār al-Kutub wa alNasyr, 1989), 17. 
masyarakat atau orang yang baru masuk Islam, di mana mereka tidak menyaksikan langsung turunnya wahyu sehingga muncul kebutuhan terhadap tafsir bahasa, hingga Islam menyebar di Timur dan Barat. ${ }^{42}$ Dalam perkembangan setelahnya, muncul tafsir tahlili dibukukannya berbagai ilmu keislaman. Banyak ilmu baru bermunculan, yang berfokus pada al-Qur'an. Penganalisaan terhadap teks al-Qur'an pun secara lebih luas dilakukan. Di masa ini kamus bahasa, juga ilmu bahasa seperti nahwu, sharaf dan baläghah, semakin berkembang. Dengan demikian muncul penjelasan terhadap ayat alQur'an secara lebih luas dalam kerangka ilmu bahasa Arab. Tujuannya adalah untuk menjelaskan kata-kata dalam al-Qur'an yang sebetulnya masih asing (gharib) dan jarang diketahui. Itu sebabnya, ditulislah berbagai kitab yang menjelaskan makna kata dalam alQur'an secara khusus, sebagai contoh, kitab Majāzul Qur'an ${ }^{43}$ karangan Abu 'Ubaidah Mu'ammar ibn Muthanna (w. 210 H/724-824 M). ${ }^{44}$ Kitab tafsir kebahasaan tersebut berbicara soal mukjizat dan keagungan al-Qur'an, menjelaskan qirāat dan gaya bahasa al-Qur'an, serta makna dan uslüb-nya. Boleh dikata, Abu 'Ubaidah adalah sebagai peletak awal atas kajian balāghah al-Qur'an dari sisi tasybih, kināyah, taqdìm dan takhīr. Meski demikian, menurut Sukamta, majāz yang dikemukakan dan dijelaskan Abu 'Ubaidah belum sepenuhnya mengakomodir keseluruhan ta'bir gaya al-Qur'an. ${ }^{45}$

Selain kitab Majāzul Qur'an karya Abu 'Ubaidah, juga ada kitab Ma'ānil Qur'an karangan Abu Zakaria Yahya bin Ziyad bin Abdullah bin Manzhur bin Marwan al-Aslami ad-Dailami al-Kufi al-Fara' (144-

\footnotetext{
${ }^{42}$ Musy'an Abdu Su'ud al-'Isawi, Tafsìr Tahlīli Tārikh wa Tathawwur (AlMu'tamar al'Ilmi as-Tsani likuliyyatil 'Ulumul Insaniyyah, 2013), 65.

${ }^{43}$ Istilah majāz dalam kitab Majāzul Qur'an karangan Abu 'Ubaidah adalah istilah yang muncul belakangan, jauh setelah masa Nabi Muhammad Saw. (abad 2 $\mathrm{H})$. Istilah tersebut pertama kali dikemukakan oleh Abu 'Ubaidah ketika hendak menulis kitab Majāzul Qur'ān tahun 207 H. Lihat Sukamta, Majāz dalam al-Qur'ān Sebuah Pendekatan Terhadap Pluralitas Makna (Yogyakarta: UIN Suka Press, 1999), 213.

${ }^{44}$ D. Hidayat, Al-Balāghah li al-Jamī' wa Shawāhid min Kalāmi al-Badī' (Semarang: PT. Karya Toha Putra, 2013), 4.

45Sukamta, Majāz dalam al-Qur'ān..., 213.
} 
207/209 H.) yang berfokus pada lafaz dari segi i'rab dan derivasinya. Selain kitab Ma'ānil Qur'an karya al-Fara', kitab Ma'ānil Qur'an karya al-Akhfasy (w. 215 H.) yang berfokus pada pembahasan al-makhārijul hurūf, aswāt, al-lughawiyah, dan qirāat, serta penjelasan terkait lafaz dan kedudukannya dalam kalam Arab secara bahasa, nahw, sharf dan balāghah. ${ }^{46}$ Kemudian, bahasan terkait 'ilm al-balāghah yang lahir dari pemikiran 'Amr ibn Baḥr ibn Maḥbub al-Kinani al-Laitsi al-Bașri alJāḥidh/al-Jahizh (159-225 H). ${ }^{47}$ Dari karya al-Jaḥidh (sekitar 250 judul buku dan risalah), ${ }^{48}$ salah satunya adalah Al-Bayān wa al-Tabyīn, yang membahas majāz, tashbìh, tamthīl, haqīqah, dan isti'ärah. Ia mengembangkan 'ilm al-bayān dengan memperjelas kerangka dasarnya melalui pembahasan al-fașāhahah ${ }^{49}$ wa al-balāghah. ${ }^{50}$ Al-Jahidh ${ }^{51}$ mengintegrasikan logika dan retorika (al-bayān) dengan menyelaraskan antara pemikiran, kata-kata, gaya bahasa dan makna. Metode yang dipakai al-Jahidh untuk mengelaborasi pemikirannya bermuara pada penghormatan terhadap akal rasional. ${ }^{52}$

Kajian tentang aspek kebahasaan terus dilakukan oleh para pengkaji setelahnya hingga menghasilkan beberapa karya seperti $\mathrm{Al}$ -

${ }^{46}$ Al-'Isawi, Tafsìr Tahlìli Tärikh..., 66.

${ }^{47} \mathrm{Al}-J a ̄ h i d h$ pernah mengunjungi Baghdad untuk berguru dan belajar bahasa kepada al-Ashmu'i (122-213 H.) dan al-Akhfash (w. 215 H.), juga belajar ilmu kalām kepada al-Naddham (w. 221 H/835 M.). Lihat Syauqi Dhaif, Tārikh al-Adab 'Așrul Islāmī (Kairo: Dār Ma'arif, 1119 H), 55.

48Syauqi Ḍhaif, Al-Balāghah Tațawwur wa Tārìkh (Kairo: Dār Ma'arif, 1119 H), 180.

${ }^{49}$ Fașāhah menurut Sirajuddin Yusuf al-Sakaki (w. 626 H.) adalah penguasaan atas makna dan lafadz dalam berbicara. Pememilihan kata-katanya tidak cacat dan mudah dipahami oleh pendengarnya. Lihat Amir Abdullah Tsabity, Al-Maākhidz 'Alā Fashāhat al-Syi' ri Ilā Nihāyati Qarni al-Rābi' al-Hijrì (Madinah: Maktabah al-Mulk Fahd, 1930), 24.

${ }^{50}$ Dhaif, Tärìkh al-Adab 'Așrul..., 66.

${ }^{51} \mathrm{Al}-J a h i$ idh dalam bidang 'ilm al-baläghah oleh sastrawan Arab diposisikan sama dengan al-Syafi'i (150-204 H) dalam bidang ușūl al-fiqh. Kalau al-Syafi'i dinilai sebagai perumus ushūl al-figh dengan Al-Risālah-nya, maka al-Jahizh dinilai sebagai pembuka pintu 'ilm al-bayān dengan karyanya Al-bayān wa al-Tabyīn. Lihat Rif'at alSharqowi, Balāghah al-'Ațfi fi al-Qur'ān Dirāsah Uslūbiyyah (Beirūt: Dār al-Nahdhah al-Arabiyah), 277.

${ }^{52}$ Ahmad Mathlub dan Husai Bashir, Al-Balāghah wa al-Tathbìq (Irak: Dār Irāqy, 1999), 201. 
Badī' $(274 \mathrm{H})$ karya Abu al-'Abbas Abdullah bin al-Mu'tazz Billah (247-296 H), 53 dikenal banyak menghimpun gaya bahasa baru dan menjadikan syair sebagai perbendaharaan contoh-contohnya; Naqd alShi'rī karya Qudāma ibn Ja'far (541-620 H), banyak merumuskan kaidah tentang kritik sastra. ${ }^{54}$

Kemudian terjadi perkembangan dalam analisa penetapan hukum (istinbat). Dalam konteks ini, mufasir mulai mengkaji nash alQur'an dari aspek figh, yang ditandai dengan munculnya kitab Ahkāmul Qur'an karangan Imam Syafi'i (w. 204 H). Kajian yang sama juga dilakukan pengikut mazhab Maliki seperti Isma'il bin Ishaq alQadhi (w. $282 \mathrm{H}$ ), kitab Aḥkām al-Qur'ān al-Karimm55 karangan alTahāwi (238-321 H), yang merupakan pengikut mazhab Hanafi. ${ }^{56}$ Pada era ini bermunculan juga kitab yang membahas tentang asbābun $n u z \overline{u l}$ seperti yang ditulis oleh Ali bin al-Madini (w. $234 \mathrm{H}$ ). Kitab tentang ilmu qirāat juga mulai ditulis seperti kitab yang dikarang oleh Abi Ubaid bin al-Qasim bin Salam (w. 224 H), Ahmad bin Zubair alKufi dan Ismail bin Ishaq al-Qadi (w. $282 \mathrm{H}$ ). Begitu juga pada era ini sudah ada pembukuan kitab ilmu nāsikh mansūkh yang dikarang oleh Qatadah bin Da'amah al-Sadusi (w.117 H), ibn Syihab al-Zuhri (w. $124 \mathrm{H}$ ) dan Muqatil bin Sulaiman (w. $105 \mathrm{H}) .{ }^{57}$

Seiring dengan adanya kebutuhan terhadap tafsir yang mencakup seluruh isi al-Qur'an, maka pada akhir abad ke-3 dan awal abad ke-4 H/10 M, muncul tafsir yang mengkaji keseluruhan isi al-

53Syadzali Abdul Ghani, Al-Badī' li ibn al-Mu'tazz Nazdārāt fì Qirāat Mu'āṣirah (Beirūt: Dar al-Ilmiyah, t.th).

${ }^{54} \mathrm{Di}$ masa pemerintahan Abbasiyah, Qudamah ibn Ja'far pernah dimintai pendapat untuk menafsirkan berbagai istilah bahasa Arab Quraisy yang berkaitan dengan ekonomi. pengetahuan yang dalam tentang sejarah syair-syair jahiliyah membuatnya lebih dikenal oleh para ahli sebagai sang pengkritik. Lihat Aan Jaelani, Muslim Scholars Contribution for European Civilization: The Roots of The History and Economic Development Tracing (Malaysia: MPRA, 2015), 7-8.

${ }^{55} \mathrm{~A} b \bar{u}$ Ja'far al-Ṭahāwi, Aḥkām al-Qur'ān al-Karìm. Edited by Sa'ad al-Dīn Aunal. 1 \& 2 (Istambul: Manshūrāt al-Buhūth al-Islāmiyyah al-Tābi' li Waqf alDiyānah al-Turkiyyah, 1995).

${ }^{56}$ Al-'Isawi, Tafsìr Tahlìli Tärikh..., 66.

${ }^{57}$ Al-'Isawi, Tafsìr Tahlìli Tärikh..., 67. 
Qur'an dan membuat model paling maju dari tafsir taḥlìlì seperti tafsir yang ditulis oleh ibn Majah, dan al-Thabari. ${ }^{58}$

Metode tafsir tahlìli merupakan metode penafsiran al-Qur'an yang digunakan oleh para mufasir klasik dan terus berkembang hingga kini. Dalam perkembangannya, kitab-kitab tafsir yang menggunakan metode ini ada yang ditulis dengan sangat panjang seperti karya al-Thabari, Fakhruddīn ar-Rāzī dan Rūh al-Ma'ānīis9 karya al-Alusi (1217-1270 H). Sementara diantara karya tafsir dengan metode tahlilì yang ditulis dengan penjelasan sedang adalah seperti tafsir karya al-Naisaburi dan Iman al-Baidhawi. Adapun contoh karya tafsir yang menggunakan metode ini dengan penjelasan yang ringkas namun jelas dan padat adalah kitab tafsir karya Jalāluddīn alSuyūṭī (1445-1505 M). ${ }^{60}$

Dengan demikian, secara teknis, para mufasir tidak seragam dalam menggunakan metode tahlìli. Artinya, ada sebagian mufasir menguraikannya secara ringkas dan sebagian ulama yang lain menguraikannya secara rinci. Dalam konteks ini, al-Farmāwī menyebut beberapa ragam tafsir taḥlīi di antaranya, tafsir bi alma'tsūr, bi al-ra'yi, shūfí, fiqhī, falsafì, 'ilmì, dan adabì al-ijtimā' $\bar{\imath} .61$

\section{Karya Tafsir}

Sebetulnya ada banyak karya tafsir berbasis tahlili yang dikarang oleh para mufasir, namun tidak cukup tempat untuk membahasnya. Sekurangnya, penulis menghadirkan beberapa di antaranya, yaitu kitab Jāmi' al-Bayān fi Ta'wìl al-Qur'ān karya ibn Jarir al-Thabari (224$310 \mathrm{H})$, Ma'ālim al-Tanzìl karya al-Baghawī $(433 / 436-516 \mathrm{H}), \quad$ Al-

${ }^{58}$ Muhammad Quraish Shihab dkk, Sejarah dan 'Ulum al-Qur'ān (Jakarta: Pustaka Firdaus, 2008), 174.

${ }^{59} \mathrm{Al}-\mathrm{Alūs} \overline{1}, \mathrm{R} \bar{u} h$ al-Ma'ānī, juz 1 (Beirūt: Dār al-Fīkr, 1978).; Al-Alūsī, Rūh alMa'ānī fì Tafsìr al-Qur'ān al-'Adzim wa as-Sab'i al-Matsānì (Beirūt: Dār al-Kutub al'Ilmiyah, 1994).

60Shihab dkk, Sejarah dan 'Ulum..., 172-173.

61'Abd al-Hayy Hussein al-Farmāwī, Al-Bidāyah fì al-Tafsīr al-Mauḍū'ì: Dirāsah Manhajiyyah Maudhū'iyyah, terj., Rosihon Anwar, Metode Tafsir Maudhū'i Dan Cara Penerapannya (Bandung: Pustaka Setia, 2002), 24. 
Muharrar al-Wajīz karya ibn 'Athiyyah (481-542 H), Al-Bahar al-Muhịt karya Abū Ḥayān (654-745 H), Al-Jāmi' li Ahkām al-Qur'ān karya alQurtubī (w. 671 H), Tafsìr al-Qur'ān al-'Azhìm karya ibn Katsir (700$774 \mathrm{H}$ ), Fathul Qadīr karya al-Syaukan̄̄ (w. $1250 \mathrm{H}$ ), Rūh al-Ma'ānì karya al-Alūsī (1217-1270 H), Majālis al-Tadzkìr karya al-Jazāirī (w. 1360 H), Tafsìr al-Tahrìr wa al-Tanwīr karya ibn 'Asyūr (1296-1393 H), dan kitab Al-Tafsìr al-Munīr karya Wahbah al-Zuhaili (1351-1437 H).

\section{Contoh Penafsiran}

1. Menyebut teks Surat al-Dhuha sebagai berikut:

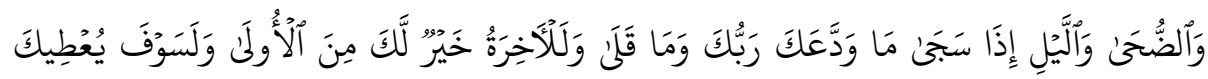

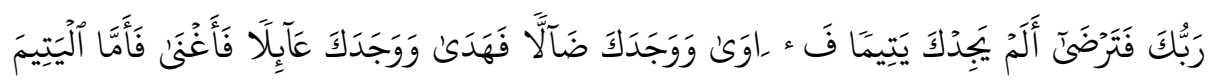

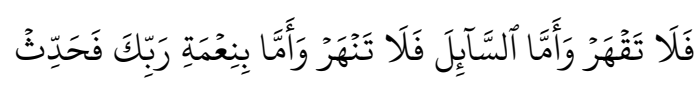

2. Menyebutkan qiroatnya, misalnya lafazh الضحس فحرى dibaca:

a. Imalah: Menurut Warsy, Nafi' Hamzah, Nafi', Hamzah, Kisa'I, Abu 'Amr, dan Khalaf;

b. Taqlil: Warsy, Nafi', Khalaf.

3. Menyebutkan asbāb al-nuzūl-nya.

4. Munasabah turunnya berdasarkan tempat dan waktunya. Misalnya surat al-Dhuha diturunkan di Kota Mekah, adapun munasabah waktunya adalah bahwa surat ini turun setelah tertahannya dan terputusnya wahyu. Para ulama dalam hal ini berselisih pendapat tentang lama tertahannya waktu, sebulan atau dua bulan, empat hari atau lebih.

5. Munasabah dengan surat sebelumnya dan sesudahnya. Misalnya surat al-Dhuha memiliki keterkaitan dengan Surat sebelumnya, yaitu Surat al-Lail. Pada surat sebelumnya, yaitu

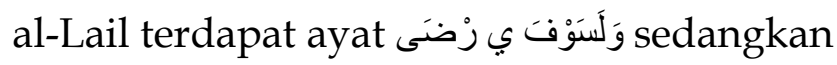

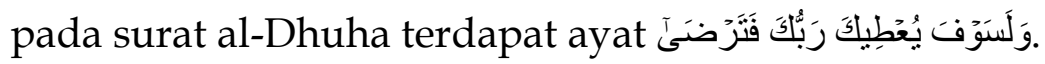

6. Analisis kalimat, Misalnya membahas kata al-dhuha dari aspek bahasanya. Contohnya mengungkap derivasi dari kata alDhuha. 
7. Menganalisis qawa'idnya. Seperti huruf J pada ayat مِنَ أَلأُوَلَى merupakan lam taukid.

8. Aspek balaghahnya. Misalnya: Surat al-Dhuha mengandung muhassināt allafzhiyyah seperti kata "tafhar" dan "tanhar" yang dalam ilmu balaghah disebut dengan jinas. Kemudian pada ayat terdapat gaya bahasa thibāq seperti pada

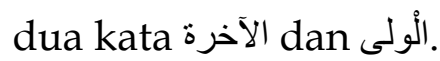

9. Interpretasi terhadap Surat al-Dhuha: Misalnya dalam Surat alDhuha Allah telah bersumpah dengan waktu dhuha. Kemudian dalam surat tersebut dijelaskan juga bahwa Allah Swt. tidak meninggalkan Nabi Muhammad Saw. dan melupakannya akan tetapi Allah Swt. menjaga dan mendidik Nabi Muhammad saw yang dulunya dalam kedaan yatim.

10. Pelajaran yang bisa diambil dari surat al-Dhuha adalah: Melalui surat ini Allah Swt. mewasiatkan bahwa ada 3 kelompok manusia yang harus diperlakukan dengan baik, yaitu: orang yang meminta-minta, yatim, dan kafir.

\section{Metode Tafsir Taḥlīin: Keunggulan dan Kelemahan}

Metode tạhlìli (analisis) adalah salah satu metode tafsir yang dalam penggunaannya memiliki keunggulan dan kelemahan sebagaimana metode tafsir sebelumnya, yakni metode ijmāli (global) dan dua metode tafsir setelahnya, muqaran (perbandingan) dan maudhu'i (tematik). Keunggulan metode ini dapat dilihat dari ruang lingkup pembahasannya yang luas oleh karena memiliki dua bentuk tafsir yaitu tafsir bi al-ma'tsūr dan bi al-ra'yi. Hanafi mengemukakan bahwa metode tahlīī memiliki keunggulan dalam penyampaian informasi yang erat terkait dengan lingkungan sosial, linguistik dan sejarah dari teks ${ }^{62}$ yang dikaji. Selain itu, tafsir tahlīi i dalam berbagai segi seperti linguistik, estetika, i'jaz dan sebagainya, lebih diarahkan pada penjelasan ayat secara independen-membuat ayat lain terabaikan, padahal masih memiliki keterkaitan. Hal ini adalah sebuah

${ }^{62}$ Hasan Hanafi, Islam in the Modern World: Religion, Ideologi and Development 1 (Heliopolis: Dār Kebaa Bookshop, 2000), 510. 
keunggulan karena membuka ruang bagi mufasir lain untuk memberikan pemikiran-pemikiran mereka dalam mengisi kekosongan tersebut.

Dengan demikian, metode ini sangat memungkinkan lahirnya berbagai gagasan dan corak disiplin baru. ${ }^{63}$ Mufasir dapat menggunakan metode ini, misalnya, tafsir bi al-ra'yi bisa dikembangkan dalam beberapa penafsiran sesuai keahlian yang dimilikinya. Ahli di bidang bahasa mendapatkan kesempatan yang banyak dan luas dalam menafsirkan al-Qur'an dari aspek kebahasaan seperti kitab Al-Musamma bi Madārik al-Tanzīl wa Haqāiq al-Ta'wìl karya an-Nasafi, ${ }^{64}$ dan kitab Al-Baḥar al-Muḥit karya Abū Ḥayān (654$745 \mathrm{H}) .{ }^{65}$ Kemudian ahli di bidang filsafat menafsirkan ayat-ayat alQur'an, yang kemudian melahirkan bahasan yang bersifat falsafī seperti kitab At-Tafsìr al-Kabìr li al-Qur'ān al-Karìm (Mafātīh al-Ghayb) karya ar-Rāzī (554-606 H). ${ }^{66}$ Sementara penafsiran al-Qur'an dari sudut teori ilmiah (sains) dapat ditemukan dalam kitab Al-Jawāhir fi Tafsìr al-Qur'ān al-Karīm karangan al-Jauharī. ${ }^{67}$

Selain keunggulan sebagaimana dijelaskan di atas, Quraish Shihab memiliki pandangan berbeda bahwa metode ini memiliki kekurangan. Menurutnya, kitab- tafsir yang memakai metode tahlìli terkesan bertele-tele dan dirasakan ada semacam belenggu yang mengikat generasi setelahnya, karena tidak jarang para mufasir memberikan pendapatnya secara teoritis dan mengesankan bahwa itulah pesan al-Qur'an yang seharusnya diindahkan setiap waktu dan tempat. Shihab juga mengatakan metode tafsir tahlīi tidak terlalu memerhatikan rambu-rambu metodologi yang harus diindahkan oleh mufasir, terutama pada saat menarik makna dan pesan dari ayat al-

${ }^{63}$ Ahmad S. Saleh, Metodologi Tafsìr al-Qur'ān Kontemporer dalam Pandangan Fazlūr Rahmmān (Jakarta: Gaung Persada Press, 2007), 51.

${ }^{64} \mathrm{Abu}$ al-Barakat an-Nasafi, Tafsir al-Nasafi: Al-Musamma bi Madārik al-Tanzīl wa Haqāiq al-Ta'wìl (Beirūt: Dar al-Fìkr, t.th).

${ }^{65}$ Abū Hayān, Al-Baḥar al-Muhịt (Beirūt: Dār al-Fīkr, 1992).

${ }^{66}$ Fakhruddīn ar-Rāzì, Mafātīḥ al-Ghayb (Beirūt: Dār al-Fīkr, 1992).

67Ṭanțāwī Jauharī, Al-Jawāhir fì Tafsīr al-Qur'ān al-Karìm, juz 1 (Mesir, Mușțafa al-Bābi al-Ḥalabiwa Aulāduhū, 1350 H). 
Qur'an, bahkan ketika menyodorkan hidangannya, terkesan bahwa semua yang dalam benak penulisnya ingin dihidangkannya sehingga mengakibatkan pembacanya menjadi jenuh. Padahal pada saat yang sama, hidangan tersebut tidak pernah tuntas dikarenakan mufasir biasanya mengarahkan pandangannya kepada ayat yang dibahasnya, terlepas dari ayat lain yang memiliki keterkaitan makna dengan ayat tersebut. ${ }^{68}$ Dalam hal ini uraian dalam tafsir taḥlìli terlalu melebar sehingga terhidang aneka hidangan yang bisa jadi sebagiannya tidak diperlukan oleh pembacanya.

\section{PENUTUP}

Penggunaan atas metode taḥlìlī dalam menafsirkan al-Qur'an dimulai pasca metode ijmālì, atau sebelum metode muqaran dan maudhu'i lazim digunakan. Mudahnya, metode taḥlìli membantu mufasir dalam mengkaji dan membuat penafsiran atas nash al-Qur'an berdasarkan urutan ayat al-Qur'an dalam mushaf yang dilihat dari berbagai sisi. Metode tahlìli dibagi oleh ulama menjadi beberapa macam, yakni tafsir bi al-ma'tsūr, bi al-ra'yi, shüfì, fiqhī, falsafì, 'ilmì, dan adabi al-ijtimā'ì. Semua bentuk metode ini memiliki ciri khasnya masing-masing. Sebagai sebuah metode tafsir, metode tahlìli memiliki ruang lingkup pembahasan yang luas dan memuat berbagai ide dan gagasan, membuatnya unggul. Meskipun demikian, metode tafsir taḥlìi tidak luput dari berbagai kekurangan seperti menjadikan petunjuk al-Qur'an menjadi parsial, penafsirannya terkadang dianggap subjektif dan masuknya pemikiran israiliat dan sebagainya. Terlepas dari keunggulan dan kekurangan metode tafsir tahlilì, dalam perkembangan tafsir dan praktiknya, ia dapat digunakan secara berdampingan dengan metode tafsir yang lain seperti ijmālì, muqaran dan maudhu'i hingga hari ini.

68Shihab, Kaidah Tafsìr, 379-381. 


\section{REFERENSI}

'Ak (al), Khālid 'Abd al-Rahman. Ușūl al-Tafsīr wa Qawā'iduhu. Beirūt: Dār al-Nafā'is, 1986.

Alūsī (al). Rūh al-Ma'ānī fì Tafsìr al-Qur'ān al-'Adzim wa as-Sab'i alMatsānì. Beirūt: Dār al-Kutub al-'Ilmiyah, 1994.

. Rūh al-Ma'ānī, juz 1. Beirūt: Dār al-Fīkr, 1978. . Manhaj al-Alusiy. Mesir: Majlis al-A'la, 1989.

Baalbaki, Rohi. Al-Mawrid: A Modern Arabic-English Dictionary. Beirūt: Dār el-'Ilm lil Malayin, 1995.

Baidan, Nashruddin. Metodologi Penafsiran al-Qur'ān. Yogyakarta: Pustaka Pelajar, 1998. . Wawasan Baru Ilmu Tafsìr. Yogyakarta: Pustaka Pelajar, 2005.

Dhahabī (al), Muhammad Husain. Al-Tafsìr wa al-Mufassirun, juz 1. Kairo: Dār al-Kutub al-Haditsah, 1986.

. Al-Tafsìr wa al-Mufassirūn 1. Kairo: Maktabah Wahbah, 2000.

. Al-Tafsìr wa al-Mufassirūn 1, cet. 2, Mesir: Dār al-Kutub alHaditsah, 1976.

Ḍhaif, Syauqi. Al-Balāghah Tațawwur wa Tārīkh. Kairo: Dār Ma'arif, $1119 \mathrm{H}$.

. Tārìkh al-Adab 'Așrul Islāmī. Kairo: Dār Ma'arif, 1119 H.

Djalal HA, Abdul. Urgensi Tafsìr Maudū'ì Pada Masa Kini. Jakarta: Kalam Mulia, 1990.

Farmāwī (al), 'Abd al-Ḥayy Hussein. Al-Bidāyah fi al-Tafsìr alMauḍh'ì: Dirāsah Manhajiyyah Maudhū'iyyah, cet. II. Kairo: Matțba'ah al-Haḍārah al-'Arabiyyah, 1977.

- Al-Bidāyah fì al-Tafsìr al-Mauḍh'̄'ì: Dirāsah Manhajiyyah Maudhū'iyyah, terj., Rosihon Anwar, Metode Tafsir Maudhū'i Dan Cara Penerapannya. Bandung: Pustaka Setia, 2002.

Ghani, Aiman A. Abdul. Al-Nahwu al-Kafi, ed. 1. Kairo: Dār alTaufiqiyyah wa al-Turats, 1998.

Ghani, Syadzali Abdul. Al-Badī' li ibn al-Mu'tazz Nazdārāt fì Qirāat $M u '$ așirah. Beirūt: Dar al-Ilmiyah, t.th.

Hamid (al), Muhsin Abd. Tathawwur Tafsìr al-Qur'ān. Dār al-Kutub wa al-Nasyr, 1989.

Hanafi, Hasan. Islam in the Modern World: Religion, Ideologi and Development 1. Heliopolis: Dār Kebaa Bookshop, 2000.

Ḥayān, Abū. Al-Bahạar al-Muhịt, (Beirūt: Dār al-Fīkr, 1992).

. Tafsìr al-Bahr al-Muhīt 1. Beirūt: Dār al-Kutub al-'Ilmiyah, 1993. 
Hidayat, D. Al-Balāghah li al-Jamī' wa Shawāhid min Kalāmi al-Badī'. Semarang: PT. Karya Toha Putra, 2013.

Husein, Ahmad bin Faris bin Zakariya Abul. Mu'jam Maqāyis alLugah, juz II. Beirūt: Dār al-Fīkr, 1979.

Ibrahim, Muhammad. Rawai' al-Bayan fì 'Ulūm al-Qur'ān. Mesir: Dār al-Taba'ah Muhammadiyah, 1984.

Ilyas, Hamim. "Hermeneutika al-Qur'ān: Studi Tafsir Modern." Tarjih: Jurnal Tarjih dan Pengembangan Pemikiran Islam 6, no. 1 (2003): 5261.

. "Kata Pengantar," dalam Studi Kitab Tafsìr. Yogyakarta: Teras, 2014.

'Isawi (al), Musy'an Abdu Su'ud. Tafsìr Tahlīli Tārikh wa Tathawwur. Al-Mu'tamar al'Ilmi as-Tsani likuliyyatil 'Ulumul Insaniyyah, 2013.

Jaelani, Aan. Muslim Scholars Contribution for European Civilization: The Roots of The History and Economic Development Tracing. Malaysia: MPRA, 2015.

Jauharī, Tanțāwī. Al-Jawāhir fì Tafsìr al-Qur'ān al-Karìm, juz 1. Mesir: Mușțafa al-Bābi al-Ḥalabiwa Aulāduhū, $1350 \mathrm{H}$.

Kamus Besar Bahasa Indonesia, (Jakarta: Balai Pustaka, 1990).

Khaeruman, Badri. Sejarah Perkembangan Tafsìr al-Qur'ān. Bandung: CV. Pustaka Setia, 2004.

Khālidī (al), Șalāh Abdu al-Fattāh. Al-Tafsìr al-Maudhū'i baina alNazhariyyah wa al-Tathbìq, ed. 1. Yordania: Dār al-Nafais, 1997.

Khalifah, Ibrahim 'Abdu al-Rahman. Al-Mausū'ah al-Qur'āniyyah alMutakhașsișah. Kairo: Al-Majlis al-A'la li al-Syuun al-Islamiyyah, 2006.

Manẓūr (ibn). Lisān al-'Arab 5. Beirūt: Dār Șādir, t.th. . Lisān al-'Arabi, juz 11. Beirūt: Dār Ṣādir, 2010.

Mathlub, Ahmad dan Husai Bashir, Al-Balāghah wa al-Tathbìq. Irak: Dār Irāqy, 1999.

Munawwir, Ahmad Warson. Kamus Al-Munawwir Arab-Indonesia. Surabaya: Pustaka Progressif, 1997.

Muslim, Muṣtafā. Mabāhith fì Tafsīr al-Maudū'ì. Damashkus: Dār alQalam, 1989.

Nasafi (an), Abu al-Barakat Tafsir al-Nasafi: Al-Musamma bi Madārik alTanzìl wa Haqāiq al-Ta'wìl. Beirūt: Dar al-Fīkr, t.th.

Qațțān (al), Mannā' Khalil. Mabāhith fì 'Ulūm al-Qur'ān. Riyāḍ: Manshūrat al-'Așr al-Hadīth, t.th. 
Rāzī (ar), Fakhruddīn. Mafātīh al-Ghayb. Beirūt: Dār al-Fīkr, 1992.

Ṣabbāgh (al), Muhammad bin Luțī. Lamhāt fì 'Ulūm al-Qur'ān wa Ittijāh al-Tafsìr. Beirūt: al-Maktab al-Islami, 1990.

Șābūnī (al), Muḥammad Ali. Al-Tỉbyān fì 'Ulūm al-Qur'ān. Jakarta: Dār al-Kutub al-Islāmiyyah, 2003.

Saleh, Ahmad S. Metodologi Tafsìr al-Qur'ān Kontemporer dalam Pandangan Fazlūr Raḥmān. Jakarta: Gaung Persada Press, 2007.

Shadr (al), Muhammad Baqir. Al-Tafsìr al-Maudhū'ì wa al-Tafsìr alTajzii fil Qur'ānil Karìm. Beirūt: Dār al-Ta'aruf.

Sharqowi (al), Rif'at. Balāghah al-'Ați fi al-Qur'ān Dirāsah Uslūbiyyah. Beirūt: Dār al-Nahdhah al-Arabiyah.

Shihab, Muhammad Quraish, dkk. Sejarah dan 'Ulum al-Qur'ān. Jakarta: Pustaka Firdaus, 2008.

. Kaidah Tafsìr. Tangerang: Lentera Hati, 2013.

- Kaidah Tafsir: Syarat, Ketentuan, dan Aturan yang Patut Anda Ketahui dalam Memahami Ayat-ayat al-Qur'ān. Jakarta: Lentera Hati, 2013.

. Membumikan al-Qur'ān. Bandung: Mizan, 1992.

- Membumikan al-Qur'ān: Fungsi dan Peran Wahyu dalam Kehidupan Masyarakat. Bandung: Mizan, 2012.

Sukamta. Majāz dalam al-Qur'ān Sebuah Pendekatan Terhadap Pluralitas Makna. Yogyakarta: UIN Suka Press, 1999.

Supiana dan M. Karman. 'Ulumul Qur'ān dan Pengenalan Metodologi Tafsir. Bandung: Pustaka Islamika, 2012.

Suyūṭi (al), Jalāluddīn. Al-Itqan fì 'Ulūm al-Qur'ān. Beirūt: Maktabah Ashriyyah, 2008. . Al-Itqān fì 'Ulūm al-Qur'ān, juz II. Beirūt: Dār al-Fīkr, 1979.

Ṭahāwi (al), Abū Ja'far. Aḥkām al-Qur'ān al-Karīm. Edited by Sa'ad alDīn Aunal, 1 \& 2. Istambul: Manshūrāt al-Buhūth al-Islāmiyyah al-Tābi' li Waqf al-Diyānah al-Turkiyyah, 1995.

Tim Penyusun Departemen Pendidikan Republik Indonesia. Kamus Besar Bahasa Indonesia (KBBI). Jakarta: Balai Pustaka, 2008.

Tsabity, Amir Abdullah. Al-Maākhidz 'Alā Fashāhat al-Syi'ri Ilā Nihāyati Qarni al-Rābi' al-Hijrì. Madinah: Maktabah al-Mulk Fahd, 1930.

Webster, Noah. Webster's New Twentieth Century Dictionary. New York: William Collins, 1980.

Wehr, Hans. A Dictionary of Modern Written Arabic. Edited by J. M. Cowan. London: Macdonald and Evans Ltd., 1995. 
Yasū'i (al), Louis Ma'lūf. Al-Munjid fì al-Lughah wa al-A'lām. Beirūt: Dār al-Mashriq, 1986.

Zarkashī (al), Badruddīn Muhammad bin Abdullah. Al-Burhān fi 'Ulūm al-Qur'ān 1. Kairo: Maktabah Dār al-Turāth, t.th. . Al-Burhān fì 'Ulūm al-Qur'ān, jilid 1. Beirūt: Dār al-Kutub al'Ilmiyah, 2008.

Zarqani (al), Abd al-'Azhim. Manāhil al-Irfān fì 'Ulum al-Qur'ān, jilid II. Mesir: Mustafa al-Babi al-Habi, t.th.

"Cambridge Academic Content Dictionary," diambil dari: https:/ / dictionary.cambridge.org/dictionary/english/analysis. Diakses pada 04 Mei 2021.

"Mu'jam al-Ma'āni," diambil dari: https://www.almaany.com/ar/dict/ar-ar/. Diakses pada 04 Mei 2021. 